\title{
Letter to the Editor: Radon isotope assessment of Submarine Groundwater Discharge (SGD) in Coleroon River Estuary, Tamil Nadu, India
}

\author{
Noble Jacob ${ }^{1}$ \\ Published online: 20 July 2018 \\ (C) Akadémiai Kiadó, Budapest, Hungary 2018
}

Dear Dr. Revay,

I have read with much interest the article "Radon isotope assessment of Submarine Groundwater Discharge (SGD) in Coleroon River Estuary, Tamil Nadu, India" authored by Prakash et al. 2018 (https://doi.org/10.1007/s10967-0185877-2) that describes the estimation of SGD in Coleroon River Estuary, Tamil Nadu, India from the continuous ${ }^{222} \mathrm{Rn}$ measurement of groundwater and pore water samples at three different locations for a period of 10 days.

In this context, I would like to state that, most of the SGD studies carried out worldwide using ${ }^{222} \mathrm{Rn}$ isotopes are based on the continuous monitoring of ${ }^{222} \mathrm{Rn}$ in coastal seawater and not by continuous monitoring of ${ }^{222} \mathrm{Rn}$ in groundwater [1-7]. Also, the SGD fluxes are generally calculated using

${ }^{222} \mathrm{Rn}$ mass balance in the coastal seawater.

However, the authors measured the temporal variation of ${ }^{222} \mathrm{Rn}$ in groundwater/pore water, and they calculate the SGD rates using the same ${ }^{222} \mathrm{Rn}$ mass balance equation $[1,5]$ derived for coastal seawater, which, according to me, is not correct.

The dynamics of coastal seawater and groundwater are completely different and are governed by various physical processes. Hence, the variation of ${ }^{222} \mathrm{Rn}$ in groundwater with respect to tidal cycles is not the same as that of coastal seawater. Therefore, the calculation of SGD rates from the variation of ${ }^{222} \mathrm{Rn}$ in groundwater is questionable.

Also, I am quite skeptical about the accuracy of ${ }^{222} \mathrm{Rn}$ measurement attaining a minimum detectable activity of

This is Letter to the Editor for the https://doi.org/10.1007/ s10967-018-5877-2.

Noble Jacob

noblej@barc.gov.in

1 Isotope Hydrology Section, Isotope and Radiation Application Division, Bhabha Atomic Research Centre, Mumbai 400 085, India
$5 \mathrm{~Bq} / \mathrm{m}^{3}$ for 20 min of counting when the sample is collected in $125 \mathrm{ml}$ bottle. The reference for the measurement procedures of ${ }^{222} \mathrm{Rn}$ in groundwater is also not cited in the paper.

Yours faithfully,

Dr. Noble Jacob

\section{References}

1. Zhang Y, Li H, Wang X, Zheng C, Wang C, Xiao K, Guo H (2016) Estimation of submarine groundwater discharge and associated nutrient fluxes in eastern Laizhou Bay, China using ${ }^{222} \mathrm{Rn}$. J Hydrol 533:103-113. https://doi.org/10.1016/j.jhydrol.2015.11.027

2. Peterson RN, Burnett WC, Taniguchi M, Chen J, Santos IR, Ishitobi $\mathrm{T}$ (2008) Radon and radium isotope assessment of submarine groundwater discharge in the Yellow River Delta, China. J Geophys Res 113:C09021. https://doi.org/10.1029/ 2008JC004776

3. Tse KC, Jiao JJ (2008) Estimation of submarine groundwater discharge in Plover Cove, Tolo Harbour, Hong Kong by ${ }^{222} \mathrm{Rn}$. Mar Chem 111(3-4):160-170. https://doi.org/10.1016/j.marchem. 2008.04.012

4. Burnett WC, Aggarwal PK, Aureli A, Bokuniewicz H, Cable JE, Charette MA, Kontar E, Krupa S, Kulkarni KM, Loveless A, Moore WS, Oberdorfer JA, Oliveira J, Ozyurt N, Povinec P, Privitera AMG, Rajar R, Ramassur RT, Scholten J, Stieglitz T, Taniguchi M, Turner JV (2006) Quantifying submarine groundwater discharge in the coastal zone via multiple methods. Sci Total Environ 367(2-3):498-543. https://doi.org/10.1016/j.scitotenv. 2006.05.009

5. Burnett WC, Dulaiova H (2003) Estimating the dynamics of groundwater input into the coastal zone via continuous radon-222 measurements. J Environ Radioact 69(1-2):21-35. https://doi.org/ $10.1016 / \mathrm{S} 0265-931 \mathrm{X}(03) 00084-5$

6. Lambert MJ, Burnett WC (2003) Submarine groundwater discharge estimates at a Florida coastal site based on continuous radon measurements. Biogeochemistry 66:55-73. https://doi.org/ 10.1023/B:BIOG.0000006057.63478.fa

7. Cable JE, Burnett WC, Chanton JP, Weatherly GL (1996) Estimating groundwater discharge into the northeastern Gulf of Mexico using radon-222. Earth Planet Sci Lett 144(3-4):591-604. https://doi.org/10.1016/S0012-821X(96)00173-2 